\title{
Opettajien ja koulukirjastonhoitajien käsitykset informaatiolukutaidosta
}

\author{
Anu Ojaranta \\ Åbo Akademi University \\ anu.ojaranta@abo.fi \\ https://orcid.org/0000-0002-8471-8778 \\ Asiasanat: informaatiolukutaito; tiedonhaku; opetus; koulut; oppilaitokset
}

Esitys perustuu väitöskirjaani, jossa tutkittiin millä tavalla informaatiolukutaito esiintyy vuosien 2004 ja 2014 perusopetuksen opetussuunnitelmissa ja miten viisi yläkoulun äidinkielenopettajaa sekä viisi koulukirjastonhoitajaa viidessä eri kouluissa ymmärtävät termin informaatiolukutaito. Informaatiolukutaito oli väitöskirjan pääasiallinen tarkastelun kohde, mutta lisäksi selvitettiin miten termit monilukutaito sekä tiedonhallintataito ymmärretään ja miten ne ymmärretään suhteessa informaatiolukutaitoon. Diskurssianalyysin avulla pyrittiin selvittämään, löytyykö informaatiolukutaidon ymmärryksestä erilaisia kahden eri ammattikunnan välisiä diskursseja.

Tutkimuskohteena olivat kaksi eri ammattikuntaa ja heidän käsityksensä informaatiolukutaidosta. Haastateltavia yhdisti samankaltainen työympäristö eli peruskoulun yläkoulu. Jørgensen ja Phillips (2002) esittävät, että organisaatiossa ilmenevät diskurssit muuttuvat ollessaan kontaktissa erilaisten diskurssien kanssa. Tämän tilanteen johdosta saattaa myös syntyä diskurssien taisteluja, jossa organisaatiossa voimakkaampi diskurssi saattaa nousta hegemonia-asemaan. Fairclough esittää, että erilaiset diskurssit ovat erilaisia representaatioita maailmasta (Fairclough, 2003, s. 124). Siksi ammattien välillä saattaa samasta asiasta olla erilaisia kilpailevia diskursseja. Vahvempi diskurssi on se, joka märittelee yleisesti organisaatiossa tehtäviä asioita ja muotoilee mahdollisesti myös organisaation diskursiivisia käytänteitä (Limberg, 2005). 
Eri opintopolkuja valmistuessamme tutustumme tiettyjen oppiaineiden kieleen ja tieteenalan diskursseihin. Opiskelijoille muotoutuu käsityksiä asioita oman tieteenalamme näkökulman kautta. Kun kohtaamme uuden termin, lähdemme sovittamaan sitä olemassa oleviin käsityksiimme. Tässä tutkimuksessa, kun termi on vieras, oli vastaajilla strategiana hajottaa yhdyssana osiin ja pohtia $\mathrm{mm}$. informaatiolukutaitoa erikseen sanojen informaatio ja lukutaito kautta. Tällöin termistä tuli informaation lukemista, joka eräälle opettajalle tarkoitti mm. bussiaikataulujen lukemista.

Informaatiolukutaito oli opettajille vieras termi. Kolme viidestä vastaajasta kertoi, etteivät he opinnoissaan ole tavanneet tällaista termiä. Yllättäen, termi ei ollut täysin tuttu kaikille koulukirjastonhoitajillekaan. Monilukutaito taas oli erittäin tuttu termi opettajille mutta hankala koulukirjastonhoitajille. Kolme haastateltavaa koulukirjastonhoitajaa viidestä kertoi suoraan, etteivät he tunne termiä, mutta heidän antamansa kuvaukset olivat oikean suuntaisia. Heillä siis oli eräänlainen käsitys monilukutaidosta multimodaalisen aineiston 'lukemisena', mutta vastaajat ilmaisivat siitä huolimatta epävarmuutta.

Tiedonhallintataidot oli termeistä kaikille vastaajille tutuin. Kaikki vastaajat kuvailivat termiä sen mukaan, miten he termin itse käsittivät. Opettajien keskuudessa termin kuvailu oli laajuudeltaan ja sisällöltään melko tasainen. Koulukirjastonhoitajien keskuudessa hajonta oli paljon suurempi, sekä laajuudeltaan että sisällöltään. Koulukirjastonhoitajilla oli myös suuria vaikeuksia erottaa termien sisällöt toisistaan, sillä useampi uskoi jo selittäneensä termin sisällön edellisen termin kohdalla, mm tiedonhallintataidot ja informaatiolukutaito. Samanlaisia toteamuksia ei opettajien toimesta juurikaan esitetty.

Lisäksi kaikilta haasteltavilta tiedusteltiin, miten näiden kolmen termin sisällöt nousevat esille vuoden 2014 perusopetuksen opetussuunnitelmassa. Kolme viidestä koulukirjastonhoitajasta ei ollut ensinkään tutustunut opetussuunnitelmaan.

Väitöskirjan tulokset käsitteiden ymmärtämisen suhteen antavat viitteitä siitä, että koulussa toimivien ammattikuntien välisiä diskursseja on olemassa. Eritavalla tai puutteellisesti ymmärretyt termit saattavat myös hankaloittaa koulun ja koulukirjaston välistä yhteistyötä. Tulosten perusteella suurimman käsityseron aiheuttaa nimenomaan informaatiolukutaito. Informaatiotutkimuksen termi ja osittain myös sen sisältö on jäänyt tutkimuksen opettajille vieraaksi.

\section{Lähteet}

Fairclough, N. (2003). Analysing discourse : textual analysis for social research. London: Routledge. Jørgensen, M. W., \& Phillips, L. J. (2002). Discourse Analysis as Theory and Method. London: SAGE Publications. 
Limberg, L. (2005). Informing information literacy education through empirical research. Teoksessa J. Henri \& M. Asselin (toim.), The Information Literate School Community 2. Issues in leadership (ss. 39-50). London: Libraries Unlimited. https://doi.org/10.1016/B978-1876938-72-7.50004-7 